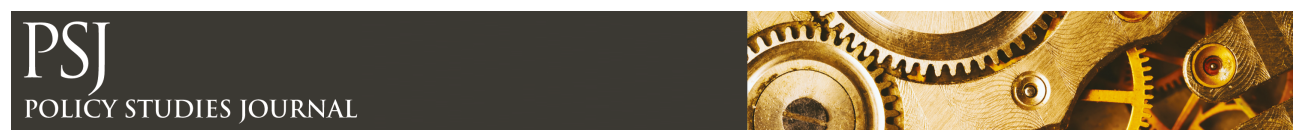

Policy Studies Journal, Vol. 0, No. 0, 2020

\title{
A Research Agenda for the Study of Policy Entrepreneurs
}

\author{
Evangelia Petridou (D) and Michael Mintrom (D)
}

The study of policy entrepreneurs as agents of change has developed greatly in recent years, supported by increasingly more sophisticated theoretical and empirical research. In this article, we first consider how the concept of the policy entrepreneur can be integrated into broader theories of the policy process, with particular focus on the compatibility of the concept with the narrative policy framework. We then propose that further empirical research on policy entrepreneurs focus on five tasks: (i) delimiting policy entrepreneurs as a distinct class of actor; (ii) investigating contextual factors that encourage the emergence of policy entrepreneurs; (iii) further specifying the strategies policy entrepreneurs deploy; (iv) improving the measurement of the impact policy entrepreneurs have in the policy process; and $(v)$ identifying when policy entrepreneurs prompt widescale change. New theoretical and empirical contributions along these lines could do much to advance our understanding of agency and structure in contemporary politics.

KEY WORDS: policy entrepreneurs, narrative policy framework, policy process theories

近年来有关政策企业家作为变革主体的研究得到了极大的发展, 这些研究受到了日益复 杂的理论及实证研究的支持。本文中, 我们首先衡量了政策企业家这一概念如何能被融入更 广的政策过程理论, 尤其聚焦于此概念与叙事政策框架的兼容性。我们随后提出, 有关政策 企业家的实证研究聚焦于五项任务：（i）将政策企业家界定为一个独特的行为者阶层; (ii) 调查鼓励政策企业家出现的背景因素;（iii）进一步确定政策企业家部署的策略; (iv) 提 升对政策企业家在政策过程中发挥的作用的衡量; (v) 识别政策企业家何时会推动大范围变 革。关于这些方向的新的理论与实证贡献能大力促进我们对当代政治中行为主体能力及架构 的理解。

关键词: 政策企业家, 叙事政策框架, 政策过程理论

El estudio de los emprendedores políticos como agentes de cambio se ha desarrollado enormemente en los últimos años, respaldado por una investigación teórica y empírica cada vez más sofisticada. En este artículo, primero consideramos cómo el concepto de emprendedor de políticas puede integrarse en teorías más amplias del proceso de políticas, con un enfoque particular en la compatibilidad del concepto con el marco narrativo de políticas. Luego, proponemos que la investigación empírica adicional sobre emprendedores de políticas se

Evangelia Petridou and Michael Mintrom confirm that they jointly contributed to the authorship of this article and that they assume joint responsibility for the text. 
centre en cinco tareas: (i) Delimitar a los emprendedores de políticas como una clase distinta de actor; (ii) Investigar factores contextuales que fomentan el surgimiento de emprendedores políticos; (iii) Especificar aún más las estrategias que implementan los emprendedores de políticas; (iv) Mejorar la medición del impacto que tienen los emprendedores en el proceso de políticas; e (v) Identificar cuándo los emprendedores de políticas impulsan un cambio a gran escala. Las nuevas contribuciones teóricas y empíricas en este sentido podrían hacer mucho para avanzar en nuestra comprensión de la agencia y la estructura en la política contemporánea.

PALABRAS CLAVE: emprendedores de políticas, marco de políticas narrativas, teorías de procesos de políticas

\section{Introduction}

Since John Kingdon popularized the concept of the policy entrepreneur in his book, Agendas, Alternatives, and Public Policies, first published in 1984, the literature on policy entrepreneurs has exploded. For centuries, entrepreneurs have been considered salient societal actors because their innovative actions disturb economic and social equilibriums (Becker, Knudsen, \& Swedberg, 2012; Kirzner, 1973, 1997; Schumpeter, 1934). The variety of influences exerted on the concept of the entrepreneur by researchers working from different disciplines and applying their distinct disciplinary assumptions has contributed to the concept's richness, versatility, and stretching. In the past few decades, while endeavors have continued to improve our knowledge of entrepreneurs in market processes (Casson, 1982; Casson \& Della Giusta, 2007), efforts have also been made to identify and describe entrepreneurial actors elsewhere in society (Battilana, Leca, \& Boxenbaum, 2009; Bornstein \& Davis, 2010; Nabutaité Aflaki, Miles, \& Petridou, 2015). The claim driving these newer explorations is that those who promote innovation in the world of politics, in policy-making processes, and within specific institutions and organizations frequently resemble entrepreneurs in the marketplace (Kingdon, 1984/2011; Mintrom, 2000; Sheingate, 2003). Indeed, common dispositions and actions can be found across entrepreneurial actors, no matter whether they are operating in market settings, political and governmental settings, or social and community settings. Policy entrepreneurs have been variously described. Kingdon memorably said policy entrepreneurs "could be in or out of government, in elected or appointed positions, in interest groups or research organizations. But their defining characteristic, much as in the case of the business entrepreneur, is their willingness to invest their resources - time, energy, reputation, and sometimes money-in the hope of a future return" (1984/2011, p. 122).

The concept of the policy entrepreneur is attractive not only because it foregrounds the role of agency in understanding policy change, an area that has been neglected (Peters, 2015), but also because it provides a palpable alternative to thin, purely rational portrayals of actors in policy-making processes. When political scientists first started noting the presence and actions of policy entrepreneurs, the portraits were sketchy. Much about why they appeared when they did, and why they 
took specific actions remained mysterious. Mark Schneider and Paul Teske (1992), frustrated by the isolated sightings and descriptions, devised a research design to transform "the notion of entrepreneurs from the study of heroic figures to the study of a larger class of individuals who help propel political and policy changes" (p. 737). The analytical rigor of Schneider and Teske's research set the stage for the flourishing of studies of policy entrepreneurs. Those studies have brought policy entrepreneurs into the light, so we can better appreciate how they drive dynamic change. Early work in this tradition included a study by Roberts and King (1996) that employed detailed case analysis and another by Mintrom (2000) that used survey-based quantitative analysis to understand what policy entrepreneurs do and the conditions under which their actions contribute to policy change.

The theoretical narrative regarding policy entrepreneurs focuses on their commitment to a policy solution, the multi-dimensional strategies they use to promote that solution, and a suite of attributes and skills underpinning their actions. Policy entrepreneurs reveal themselves through their attempts to transform policy ideas into policy innovations and, hence, disrupt status quo policy arrangements. This distinguishes them from many interest group leaders, for whom maintenance of current institutional settings and power relations is paramount. In studying the political work of policy entrepreneurs, we can gain insights into what it takes to promote significant policy change.

For some years now, scholars have explored strategies adopted by policy entrepreneurs to advance their advocacy activities. The relevant studies have employed a variety of research designs. Consequently, we now understand that policy entrepreneurs work at problem framing, team building, networking, leading by example, and exploring ways to scale up change processes (Mintrom, 2000, 2019). Policy entrepreneurs can often advance their goals through careful interpretation and portrayal of the current situation. Such actions, broadly construed as problem framing, are always political. They involve assembling new evidence and the making of novel arguments, all with the intention of changing political alignments and, hence, the status quo (Dewulf \& Bouwen, 2012; Mintrom \& Luetjens, 2017; Shpaizman, Swed, \& Pedahzur, 2016). Team building is also crucial to policy entrepreneurship. Through careful construction of teams, it is possible for a policy entrepreneur to find effective ways to leverage the knowledge and skills of others towards a common goal (Mintrom, Salisbury, \& Luetjens, 2014; Roberts \& King, 1996). The logic of team building also extends to developing advocacy coalitions or working with existing ones (Litfin, 2000; Meijerink \& Huitema, 2010; Mintrom \& Vergari, 1996). Policy networks, as repositories of knowledge, know-how, war stories, and professional gossip, can be vital sources of information for policy entrepreneurs. Knowing how to effectively tap local and broader networks can do much to help policy entrepreneurs advance their advocacy efforts. Engagement in cross-jurisdictional networks can help policy entrepreneurs amass the kind of evidence they need to convince decision makers that a proposed change is attractive and effective. Meanwhile, engagement in networks in and around government in their home jurisdictions is vital for gaining legislative adoption (Arnold, Nguyen Long, \& Gottlieb, 2017; Christopoulos \& Ingold, 2015; Mintrom \& Vergari, 1998). Risk aversion among decision makers 
presents a major challenge for actors seeking to promote significant policy change. In response, policy entrepreneurs often take actions intended to reduce opposition to change. This is what we mean when we say they can show leadership by example. A common strategy involves engaging with others to establish demonstration projects or accumulate other "facts on the ground" (Falleti, 2010; Mintrom, 1997). Finally, policy entrepreneurs often seek ways to tell their stories and work with others to scale up policy changes from one location-such as a local government setting - to a broader jurisdiction - a state, province, or nation (Faling, 2019; Lu, Mayer, Wellstead, \& Zhou, 2020; Mintrom \& Thomas, 2018; Tang, Cheng, \& Cai, 2020).

As the salience of agency in policymaking has been further explored, scholarship has continued to develop and adjust the conceptualization of the policy entrepreneur as an agent of change (e.g., Hammond, 2013; Mintrom, 2000; Mintrom \& Vergari, 1996; Roberts \& King, 1991; Schneider, Teske, \& Mintrom, 1995). Our understanding of the strategies entrepreneurs use (e.g., Cairney, 2018; Frisch-Aviram, Cohen, \& Beeri, 2019; Meijerink \& Huitema, 2010; Mintrom, 2000; Mintrom \& Luetjens, 2017; Petridou, 2018; Petridou \& Sparf, 2017), the policy areas in which they are active (e.g., Callaghan \& Sylvester, 2019; Huitema \& Meijerink , 2010; Mintrom et al., 2014), and in which level of governance they might emerge (e.g., Carter \& Scott, 2009; Frisch-Aviram, Cohen, \& Beeri, 2018; Golan-Nadir \& Cohen, 2017; Schneider et al., 1995) have been refined through increasingly sophisticated and nuanced research.

Recent examples of such research illustrate both the many substantive topics being explored with a focus on policy entrepreneurs and the diverse range of research methods being employed to do so. To give a sense of this range and diversity of contributions we note systematic reviews of large bodies of literature by teams of authors aimed at refining our knowledge on strategies used by policy entrepreneurs (Faling, Biesbroek, Karlsson-Vinkhuyzen, \& Termeer, 2018; Frisch-Aviram et al., 2019), a quantitative approach to understanding the influence of individual policy entrepreneurs on American legislators (Anderson, DeLeo, \& Taylor, 2019), a large $N$ quantitative to study the impact of policy entrepreneurs at the local level in the field of fracking (Arnold, 2020), an analysis of international policy entrepreneurship (Mintrom \& Luetjens, 2019), a study of policy entrepreneurship among public servants pursuing policy integration (Svensson, 2019), and an account of how individual concerned citizens may become policy entrepreneurs (Callaghan \& Sylvester, 2019). This selective list of recent research is intended only to give a sense of the growing attention being given to policy entrepreneurs and the variety of approaches through which their actions are being studied.

This article proceeds in two main sections. In the first, we build on previous considerations of how the role of the policy entrepreneur can be integrated into broader theories of the policy process. In 2009, Michael Mintrom and Philippa Norman showed how the role of the policy entrepreneur could be integrated into established theories of the policy process. Theorization of the policy process is dynamic. Established theories are continually being refined, new theories are continually being developed (Petridou, 2014; Sabatier \& Weible, 2014; Weible, 2018). Thus, the integration of the policy entrepreneur in current theories must necessarily be updated and developed as well. After briefly summarizing prior insights, we 
investigate the compatibility of concept of the policy entrepreneur with the narrative policy framework (NPF; Jones \& McBeth, 2010). We contend that such an investigation is useful both for advancing our understanding of how motivation influences narrative construction and for revealing how elements of this framework could usefully advance conceptualizations of what policy entrepreneurs do.

The rationale for focusing on NPF stems from the theoretical origins of the policy entrepreneur in the multiple streams framework, which views problems and the severity of these problems as social constructions rather than objective facts (Herweg, Zahariadis, \& Zohlnhöfer, 2018). Kingdon (1984/2011) pointed out the difference between a condition and a problem: we all tolerate conditions in our daily lives (such as bad weather); a problem becomes a problem when it is interpreted as a situation which can be solved by collective action (see also Jones et al., 2016). As Schneider et al. (1995, p. 103) note "[a]ll entrepreneurs must solve collective action problems." The salience of agency when defining a situation as a (policy) problem in the guise of policy entrepreneurship is high because policy entrepreneurs must be able to argue persuasively (Mintrom, 2000). The salience of agency is high in NPF as well, as it is a policy process theory which explicitly views the policy world through a social construction lens, embracing the notion that policy problems and the whole policy process strongly depend on the meaning attached to them by the actors involved (Jones \& Radaelli, 2015, p. 341).

Policy entrepreneurs have played the role of meaning-makers and interpreters of problems through the use of a multitude of strategies and reliance on a wide skillset. For this reason, a detailed exploration of the role of policy entrepreneurs in the NPF is not only justified, but also a fruitful way to advance both the scholarship on policy entrepreneurship and further NPF research.

Our consideration of how policy entrepreneurs fit conceptually with broader theories of the policy process sets the scene for the second section of this article. There, we identify and discuss interrelated approaches to advancing research on policy entrepreneurs. The approaches are not necessarily novel, but we propose ways to advance their scope and depth. Critics of the concept of the policy entrepreneur have accused it of fuzziness, meaning different things to different scholars even within the same discipline (Cairney, 2013; Petridou, 2017). Such criticisms can be addressed through further research. In our view, there are five areas where research could fruitfully advance our knowledge of the role played by policy entrepreneurs in the policy-making process. These are: (i) delimiting policy entrepreneurs as a distinct class of actor, (ii) investigating contextual factors that encourage the emergence of policy entrepreneurs, (iii) further specifying the strategies policy entrepreneurs deploy, (iv) improving the measurement of the impact policy entrepreneurs have in the policy process, and (v) identifying when policy entrepreneurs prompt widescale change.

This is not an exhaustive research agenda for the study of policy entrepreneurs. Rather, it builds logically from the existing body of research. Given how the literature has developed in recent decades, we are confident that new research in each of these five areas will do much to improve our knowledge of how policy entrepreneurs drive public policy change. Evidence from around the world indicates that in 
the current era, myriad established public policy settings from the national to the local level are ripe for change. Policy scholars, political scientists, and many people in and around government who desire to drive change could benefit from new insights into what policy entrepreneurs do-and how and why their actions make a difference. This article is intended to prompt new research that will deliver such insights.

\section{Policy Entrepreneurs Within Theories of the Policy Process}

In seeking to promote policy change, policy entrepreneurs must be immersed in policy-making processes, which are inherently political, complex, and combative. As the field of policy studies has evolved, various theories of policymaking have been advanced and developed. Here, we briefly summarize five classic ones: incrementalism, institutionalism, the multiple streams framework, punctuated equilibrium theory, and the advocacy coalition framework. Following Mintrom and Norman (2009), after explaining key features of each theory, we consider the compatibility between the theory and the concept of the policy entrepreneur. Having established this analytical approach, we then apply it to considering the compatibility between the concept of the policy entrepreneur and the more recently advanced narrative policy framework (Jones \& McBeth, 2010). We believe considerable room exists here for future explorations of policy entrepreneurs and the construction of policy narrative. Locating policy entrepreneurs in theories of the policy-making process helps us to consider when and how policy entrepreneurs might be most likely to meet with success, and what combination of conditions and actions could increase their chances of securing policy change.

\section{Policy Entrepreneurs and Classic Theories of the Policy Process}

Incrementalism. Advanced by Charles Lindblom (1959, 1979), incrementalism posits that most change within policymaking occurs through small steps pursued by risk-averse policymakers. Lindblom rejected the notion that policymakers follow a rational choice strategy in the process of defining the problem, laying out alternative solutions, predicting the consequences, valuing the outcomes, and making a choice. Even if a single actor intended to act rationally, complexity would soon make the exercise of rational choice impossible. The potential for rational choice is further stymied because reasonable people can be expected to disagree about many aspects of a policy issue. Complexity and disagreement reduce the odds that bold policy responses will ever be adopted with unanimity. Incrementalism is the result.

Even though incrementalism may seem frustrating, Lindblom (1968) characterized it as a "shrewd, resourceful" way of wrestling with complex problems. He argued that focus should be placed on the behavior of proximate policymakers, anyone with decision-making authority: legislators, political executives, appointed bureaucrats, and some party officials. Proximate policymakers operate within a "play of power" governed by institutional structures, or the rules of the game, that 
include the provisions of relevant constitutions, legislative acts, administrative rulings, executive orders, and judicial decisions. Policy choices emerge from structured interactions among proximate policymakers.

In this conception of policymaking, policy entrepreneurs might come from the ranks of proximate policymakers or they might be more on the margins of policy-making circles. According to Lindblom, the key to successfully engaging proximate policymakers is to present your argument in an appealing form. Likewise, proximate policymakers can be influenced by their assessments of the interests represented in a policy entrepreneur's coalition, and the size and strength of it. While incrementalism presents a frustrating inhibitor to dramatic change, patient actors with clear goals can still move policy in directions they desire. Consistent with this interpretation, Falleti (2010) showed how policy entrepreneurs pursued major health policy change through incrementalism. In a very different context, Shpaizman et al. (2016) showed how working the margins of current laws can advance specific policy goals, even in a climate where entrenched political differences make any change difficult.

Institutionalism. Through much of the twentieth century, institutional accounts of government processes were highly descriptive, describing features of government agencies and processes and making normative assumptions about how people acted within them. When political scientists became enamored with behaviorism and using incentives to explain individual action, institutionalism went out of fashion as a way of interpreting policy-making processes (Easton, 1969). This began to change when scholars like the economic historian Douglas North $(1981,1990)$, the sociologist Theda Skocpol and her colleagues (e.g., Evans, Rueschemeyer, \& Skocpol, 1985), and the political scientists James March and Johan Olsen $(1983,1989)$ started exploring interactions between individuals and institutions. Various institutionalist perspectives then emerged, all emphasizing the agency of individuals and groups within broader structures (Hall \& Taylor, 1996). Several influential lines of scholarship developed, collectively referred to as "the new institutionalism" (March \& Olsen, 1983; Powell \& DiMaggio, 1991). The common element was the focus on institutional design and how specific design features incentivized specific actions (Ostrom, 2009).

Institutionalist accounts of the policy process and policy change identify considerable space for motivated individuals and groups to have impact (Mettler, 1998; Sheingate, 2003). However, these accounts also explain the limits of such activism. For example, in highlighting "the logic of appropriateness," March and Olsen (1989) showed the importance of actors having deep knowledge of relevant procedures and norms of acceptable behavior. Institutional accounts suggest insider sensibilities are critical to effectiveness in the pursuit of policy change.

Institutionalist accounts open space for policy entrepreneurs (Feldman \& Khademian, 2002; Scharpf, 1997). However, those promoting policy change must appreciate the intricacies of political systems. Policy entrepreneurs must be able to understand the workings of a given context without becoming so embedded in it that they lose their critical perspective and their motivation to promote policy innovations. Evidence suggests policy entrepreneurs can be successful in this regard 
when they make good use of networks (Mintrom \& Vergari, 1998) or when they form teams that contain both "insiders" and "outsiders" (Mintrom et al., 2014; Roberts \& King, 1996). Recent literature has highlighted the "boundary spanning" efforts of policy entrepreneurs (Faling et al., 2018). This allows them to tap knowledge of distinctive institutions and processes with the purpose of building support for policy change (see also Ohemeng \& Kamga, 2020).

The Multiple Streams Framework. Advanced by John Kingdon (1984/2011), this framework posits that agenda setting and policy change emerge through a combination of actions by individuals and the operations of formal and informal social processes. Many individuals can call attention to specific policy issues. But it is primarily elected officials who decide which issues will become agenda items and hence who set the scene for discussion of policy change. Kingdon argued that policy issues emerge on government decision-making agendas as the result of developments in three separate process streams: the problem stream, the policy stream, and the political stream. In so doing, he crystalized the concept of the policy entrepreneur, claiming that policy entrepreneurs often serve to join these three independent streams, identifying and exploiting "windows of opportunity."

In the multiple streams framework, the problem stream is where efforts are made to draw attention to issues and encourage a policy response. Those benefiting from the status quo face incentives to convince others that no problem worthy of government attention exists. Those seeking to highlight a problem, aside from demonstrating the problem's significance, must show that policy solutions are available. In the policy stream, communities of policy specialists generate and debate numerous ideas for policy solutions. Occasionally, members of these communities come up with new ideas for policy solutions, but mostly reformulate or recombine old ones. Even though ideas often sweep policy communities, governments typically react slowly in response. To survive, ideas must be perceived as workable, and must be compatible with the values of a majority of specialists in the relevant policy community. The political stream is composed of things like election results, changes in administrations, changes in the partisan or ideological distribution of legislatures, interest-group pressure campaigns, and changes in public opinion or the national mood. Changes in the political stream and occasional changes in the problem stream, like focusing events, provide the major opportunities for agenda changes in government. Agenda change can come rapidly at times, but organized political forces can serve as a brake. For even the possibility of major policy change to arise, serious amounts of bargaining and coalition building in the political stream typically must occur. Various contributions have been made to advance conceptual refinement and stretch the empirical testing of this framework (e.g., Dolan, 2019; Goyal, Howlett, \& Chindarkar, 2020; Herweg et al., 2018; Jones et al., 2016).

Punctuated Equilibrium Theory. A discrepancy exists between accounts of why policy change occurs slowly and the multiple streams framework, which opens space for instances of dramatic policy shifts. To reconcile these accounts, Frank R. Baumgartner and Bryan D. Jones conceptualized the policy process as characterized by punctuated equilibrium. In this conception, policymaking in specific areas of 
activity often experiences long periods of stability interrupted by moments of abrupt, significant change (Baumgartner \& Jones, 1993/2009). Echoing Lindblom (1959), Baumgartner and Jones suggest stability is the product of the inability of legislators to attend to more than a few issues at a time. Stability is further supported by the emergence of policy monopolies, controlled by people who go to considerable lengths to promote positive images of current policy settings and deflect calls for change. In this interpretation of policymaking, the task for advocates of policy change is to bring the policy issues into the public arena and invoke a groundswell of change-forcing interest. Even within stable systems, the potential for change exists. The challenge for those seeking such change is to undermine existing present policy images and create new ones that emphasize major problems and why the status quo is not sustainable.

Baumgartner and Jones note that it is possible for policy changes to occur in multiple venues. When policy change appears blocked at one level (e.g., the national government level), it might be effectively pursued elsewhere (e.g., at the state or local level). This suggests efforts to establish new ways of doing things in one venue can create momentum for change across a whole system. For example, many statelevel leaders in the United States have introduced major changes that other states subsequently adopted. Further, these state-level changes can serve to change conversations at the federal level. Drawing on the work of Baumgartner and Jones (1993/2009), many studies have subsequently explored linkages between the actions of policy entrepreneurs and the initiation of rapid policy change. These include contributions by Bakir (2009), Carter and Jacobs (2014), and Hammond (2013).

The Advocacy Coalition Framework. Paul A. Sabatier's (1988) theorization of policy change generated the advocacy coalition framework and subsequent refinements of it (e.g., Sabatier \& Jenkins-Smith, 1993; Weible \& Sabatier, 2009). According to Sabatier, advocacy coalitions consist of "people from a variety of positions (e.g., elected and agency officials, interest group leaders, researchers) who share a specific belief system-i.e., a set of basic values, causal assumptions, and problem perceptionsand who show a nontrivial degree of coordinated activity over time" (Sabatier, 1988, p. 139). Coalition participants seek to ensure the maintenance and evolution of policy in specific policy domains. Within the advocacy coalition framework, change comes from both internal and external sources. But, to have political effect, those catalysts for change need to be appropriately interpreted and translated. This process of translation takes, for example, objective social, economic, and environmental conditions and portrays them in ways designed to increase the likelihood that they will receive the decision makers' attention.

The advocacy coalition framework reminds us that policymaking involves a large number of actors and organizations and that change emerges from conversations among these entities. Shared meanings and interpretations operate as mechanisms for making sense of specific new developments-which can emerge from changes in the natural environment, technical innovation, or political realignments. Policy entrepreneurship is not treated explicitly within the framework. However, there is room for compatibility. For example, endogenous and exogenous shocks 
need to be interpreted within the coalition before responses are devised and agreed. The process of interpretation has similarities with problem definition, a key strategy used by policy entrepreneurs. Mintrom and Vergari (1996) considered the link between formation and maintenance of advocacy coalitions and the efforts of policy entrepreneurs. In subsequent studies, Goldfinch and 't Hart (2003), Litfin (2000), and Meijerink and Huitema (2010), among others, have shown the merits of incorporating a discussion of policy entrepreneurship within discussions of advocacy coalitions.

\section{Policy Entrepreneurs and the Narrative Policy Framework}

The narrative policy framework has risen to prominence as a theory of the policy process over the past decade. Michael D. Jones and Mark K. McBeth (2010) argued that policy narratives can be studied using systematic empirical approaches. They set forth a formal framework for elaboration and empirical testing. The framework has been most recently summarized by Elizabeth A. Shanahan, Michael D. Jones, Mark K. McBeth, and Claudio M. Radaelli (2018), whose discussion we draw upon here.

The narrative policy framework investigates the empirical role of policy narratives in the policy process by asking "[d]o narratives play an important role in the policy process?" (Shanahan et al., 2018, p. 173). This is not an insignificant question as narratives shape political debates in formal and informal venues alike and are considered influential in different stages of the policy process. Policy narratives are strategic stories consisting of a setting (political context); characters (heroes and villains, beneficiaries, allies, and opponents); a plot; and a moral of the story-the outcome designed for the public good (Jones \& McBeth, 2010; Petridou, 2014; Shanahan, McBeth, \& Hathaway, 2011).

According to the narrative policy framework, the narrator's intention is to influence the policy process. To do so, the narrator can deploy a range of "policy narrative strategies." Shanahan et al. (2018) highlight three such strategies. First, following E. E. Schattschneider's (1960) classic formulation of political action, it is expected that narrators who perceive themselves as losing will attempt to expand the scope of conflict, whereas those who believe they are winning will attempt to contain the issue and retain the status quo. Second, following Stone (2002), narrators are expected to ascribe causal mechanisms to situations in a fashion that serves to assign responsibility and blame for specific outcomes. These casual mechanisms could highlight that outcomes were intentional, inadvertent, accidental, or mechanical. Third, following work by Paul Sabatier and colleagues, narrators are expected to deploy the "devil-angel shift." The "devil shift" occurs when the narrator exaggerates the malicious motives, behavior, and influence of opponents" (see Weible, Sabatier, \& McQueen, 2009). The "angel shift" occurs when narrators emphasize their ability to solve a problem and de-emphasize the agency of opponents (Shanahan et al., 2014).

Within the narrative policy framework, policy actors and narrative authors may come from an array of institutions or organizations and they may serve a variety 
of roles within them (Shanahan et al., 2018). Actors highlighted for special attention are "policy marketers." Policy marketers could emerge from various positions in and around government. For example, the role could be played by members of an interest group, by people in the media, or by elected officials. Policy marketers "spend much of their time constructing public policy problems, defining relevant policy beliefs, and ultimately reducing complex and interrelated societal problems into simple policy marketing packages" (McBeth \& Shanahan, 2004). Problem definition is a "strategic representation of situations" (Stone, 2002, p. 133) because it involves defining a goal and the difference between it and the status quo. This strategic representation is not consistent among different groups, but rather, it is a means of promoting their interests and point of view. Policy marketers are a kind of elite actor and their narratives may be geared toward not only the public in their effort to shift public opinion, but also toward other actors in the policy process (Shanahan et al., 2018).

Others before us have noted the potential for actors described as "policy marketers" to approximate policy entrepreneurs (e.g., Lawton \& Rudd, 2014). In our view, policy entrepreneurs could be construed within the narrative policy framework as more than just another character in the narrative. Indeed, we suggest that considerable value could come from research that posits the policy entrepreneur as a potential author of the narrative that is, as a policy marketer. This direct insertion of the concept of the policy entrepreneur as a central player in the narrative policy framework holds the potential to further enrich theorization of the policy-making process and guide new empirical explorations. In the remainder of this section, we demonstrate how such an "insertion" might work.

The policy marketer as the policy entrepreneur. Using the Greater Yellowstone Area as the empirical setting, McBeth and Shanahan (2004) explained how different groups, including interest groups, the media, and elected officials, act as policy marketers. Subsequent literature has called for a better understanding of how individual elite actors use and interpret narratives.

The recent focus on strategic actions of policy entrepreneurs-especially their policy framing efforts (see, e.g., Mintrom \& Luetjens, 2017)—opens space for investigating cases where policy entrepreneurs take actions consistent with those of the policy marketers. Utilizing the narrative policy framework in a fashion that involves investigating conceptual and empirical points of intersection between the strategies of policy entrepreneurs and the strategies of policy marketeers has the potential to significantly advance our knowledge of how these strategic authors and peddlers of narrative policy go about their work. It may provide a more nuanced picture of how policy marketers go about authoring and promoting a narrative as well the narrative's consequences within the entire policy process. The narrative policy framework encourages researchers to explore how micro-level actions serve to change narratives at the meso- and macro-level in policy processes. At the same time, research on points of intersection between the strategies of policy entrepreneurs and the strategies of policy marketers could greatly improve our understanding of how policy entrepreneurs engage in problem framing. The work of Mintrom and Luetjens (2017) has helped, but there is plenty of room for more nuanced and rigorous studies. 
Since the narrative policy framework posits that narratives are strategically constructed, it follows that the author of the narrative has a strategic plan in place. Potentially, such a plan could span the entirety of the policy process, with the intent of ensuring the success of a preferred policy change. Policy marketers as policy entrepreneurs may be willing to risk their resources and proceed stepwise to mitigate such risk and shift the arena of decision if they deem that the chances of their policy narrative serving to support policy change would be effective in a different governance level.

The strategies concerning different aspects of the relational management of policy marketers as policy entrepreneurs also have a potential to move the narrative policy framework forward. Meanwhile, identifying the policy marketer as the policy entrepreneur would broaden the scope of the policy entrepreneur and further illustrate the concept's versatility. Potentially, it would also provide additional perspectives on how policy entrepreneurs structure their narrative and connect the structure to policy success or failure.

\section{Summary}

We have reviewed the compatibility of the concept of the policy entrepreneur with well-established theories of the policy-making process. Such a review is important for two reasons. First, conceptual discussions of policy entrepreneurs must pay appropriate attention to the structures in which these actors seek to exercise their agency. Broader theories of the policy-making process point us to both the opportunities and constraints that all actors face, including policy entrepreneurs. Throughout our discussion, we have noted innovative studies where researchers have produced new insights into how policy change occurs by assessing the compatibility of the concept of the policy entrepreneur with specific theories of the policy-making process. This takes us to our second important reason for theoretical discussion. That is, investigations of this kind can be generative, signposting new areas for theoretical exploration and empirical testing. Our discussion of policy entrepreneurs and the narrative policy framework has done just that. Much innovative and potentially insightful research could flow from deeper investigation into the points of convergence and divergence in the strategies deployed by policy marketers as authors and narrators and policy entrepreneurs as aspiring agents of change.

\section{Advancing Research On Policy Entrepreneurs}

In this section, we show how a set of five new approaches to research on policy entrepreneurs might lead to a greater understanding of these actors and their contributions to policymaking. The approaches we discuss are not necessarily novel, but further research along these lines could usefully advance our understanding of the work of policy entrepreneurs, why they do what they do, and their capacity to drive change in specific contexts and across broader systems. We will now discuss each in turn. 
Since policy entrepreneurs may be active inside or outside formal governmental institutions at any level, be part of an interest group, hold elected or appointed office, work for research organizations, or be concerned citizens (Kingdon, 1984/2011; Schneider et al., 1995), policy entrepreneurship is not a formal role, but rather a set of strategies, attributes, and skills combined with an intentionality underpinning the actions of actors. The scholarship in the field is in agreement that they comprise a distinct class of political actor. This has two implications for the identification and the subsequent study of policy entrepreneurs.

First, and ontologically speaking, rigor is required in pinpointing what is unique about policy entrepreneurs. "[A]ll that is required for entrepreneurial behavior is that an actor discovers and acts on an opportunity, and these opportunities exist in every social arena" (Shockley, Stough, Haynes, \& Frank, 2006, p. 210). Since the concept is borrowed from the field of economics, policy entrepreneurs, like their market counterparts, are purported to possess ambition, social acuity, credibility, sociability, and tenacity. They also exhibit skills such as strategic thinking, team buidling, collecting evidence, making arguments, engaging diverse audiences, negotiating and networking (Mintrom, 2019). However, having these attributes and skills alone does not necessarily make an actor an entrepreneur; they are necessary but not sufficient. The policy entrepreneur must be willing to use their attributes and skills in investing resources at their disposal toward a goal, broadly framed as effecting change. Additionally, extant research does not offer great insights into the relative importance of attributes and skills — for example, is social acuity more or less important than tenacity when it comes to the success of policy entrepreneurial activities? Perhaps the most researched attribute is sociability, to the extent that it is structurally observable through the study of social and political networks (Arnold et al., 2017; Christopoulos, 2006; Ingold \& Christopoulos, 2015; Petridou, 2018).

Second, and from an epistemological perspective, nuance is needed in the identification of the policy entrepreneur. So far, the policy entrepreneur is identified by the researcher (e.g. Mintrom, 2013) or by a proxy with contextual expertise (Anderson et al., 2019; Mintrom, 2000). Identification of entrepreneurs is based on qualitative criteria - an accepted practice, but one that leaves room for bias. Additionally, being a policy entrepreneur has been a dichotomous affair-either one is, or one is not.

Though transparency on the part of the researcher and contextual expertise on the part of the proxy identifier go a long way towar minimizing bias, a survey-based tool would go even further. The binarity of the policy entrepreneur does not allow for nuances in their theorization and leaves us with blunt investigative tools. This instrument would have the potential to reveal the nuances of policy entrepreneurs in a comparative design: entrepreneurship would be measured among individuals deemed to be policy entrepreneurs, as well as in between them and other, non-entrepreneurial actors active in similar contexts. Such a design would allow us, for example, to start specifying the relative extent to which the success of policy entrepreneurs is due to attributes, skills, effective strategies, or relevant contextual features. 
Finally, a quantitative instrument would mitigate the salience of the occurrence of change in designing a study. Often, researchers start from a change that has occurred and work backward, identifying possible policy entrepreneurs (though see Mintrom, 2015, for a study of failure). This is to say that the study of the entrepreneur would not have to be associated with their success. Further, an understanding of the attributes, skills, and strategies of policy entrepreneurs as a distinct class of actors opens the possibility of separating the degree to which aspects of policy entrepreneurship result from underlying attributes versus learned skills and strategies.

Rigor in delimiting policy entrepreneurs as a distinct class of political actor may facilitate distinguishing the contingences engendered by their other political identities as well as the fluidity that characterizes them. We also anticipate that efforts to delimit policy entrepreneurs as a distinct class of actor would open up new areas for investigation. For example, as we learn more about the distinctive features of policy entrepreneurs, we are likely to become more attuned to variation within this class of actor. We note, for example, that policy entrepreneurship seems to entail risk-taking, just as entrepreneurship in the market does. However, risk-taking is common to many professionals - even university professors can be construed as risk-takers, in terms of the choices they make about career moves, secondments, and the topics they choose to work on. So, we really need to think harder about the extent to which risk-taking represents a defining characteristic of policy entrepreneurship. By doing so, we would likely find that some are more risk-seeking than others. That could lead into useful explorations of risk and expected return, a topic that is yet to receive formal treatment in the literature on policy entrepreneurship.

\section{Investigating Contextual Factors that Encourage the Emergence of Policy Entrepreneurs}

The different identities held by individual policy entrepreneurs are also part of the broader context influencing their emergence, the scope of the strategies they may use, and the possibility of their success in effecting change. Here, we discuss four aspects of context where more research could be productive. These are as follows: first, the stage of the policy-making process in which they are active; second, the substantive policy sector in which they wish to effect change; third, the broader system or level of government in which they are active; and fourth, how they relate to others within their operating context. Various questions arise when we think about contextual factors that encourage the emergence of policy entrepreneurs. For example, how do contextual factors influence their emergence? Relatedly, how do contextual factors influence the way policy entrepreneurship plays out in specific policy-making settings? Further, if policy entrepreneurs are defined by the actions they take, who may act entrepreneurially in one instance but not in another?

The other identities of policy entrepreneurs partly determine, inter alia, the resources in their disposal-they also delimit a set of appropriate strategies, both in qualitative terms and in terms of scope. For example, where a national politician may engage in broad fund-raising activities appealing to private donors (Meydani, 2015), a municipal public servant may do so through applying for governmental 
grants (Petridou, 2018); a Director General in the European Union may select a solution produced through a policy spillover by another Directorate General (Ackrill \& Kay, 2011), a private citizen seeking to change policy in the United States may testify in hearings as a means of bringing attention to a policy problem (Callaghan \& Sylvester, 2019).

Policy entrepreneurs tend to focus on specific stages of policymaking. Bringing attention to a policy problem and setting the agenda was the initial focus of the literature on policy entrepreneurs (Herweg et al., 2018; Kingdon, 1984/2011; Zahariadis, 2014). However, recent literature has investigated policy entrepreneurship in the implementation stage (Frisch-Aviram et al., 2018; Howard, 2001; Petridou, 2018). Other stages of the policy-making process remain understudied. An obvious instance is the stage of policy evaluation. In separate studies, Frisch-Aviram et al. (2018) and Petridou (2018) have reported that entrepreneurs insert themselves in the evaluation process. Given the salience of policy evaluations, especially in evidence-based policymaking, finding out more about how policy entrepreneurs engage with policy evaluation would appear a fruitful avenue of future research. There is large variation in the use of evaluations in the policy process. This can be the case even when it is not expected, such as between countries sharing many things in common in terms of governmental systems and policy design. For example, Knill and Tosun (2012) reported that Germany and Sweden were pioneers in the use of evaluation in Europe, followed by Denmark, France, the Netherlands, and the United Kingdom. Other European countries, such as Belgium, lag further behind (see also Varone, Jacob, \& de Winter, 2005; Viñas, 2009).

Policy entrepreneurs are typically studied within specific policy domains. The literature on policy entrepreneurs clearly illustrates that they are active in a variety of policy sectors. These diverse policy sectors are selected as contexts for the study of the strategies of policy entrepreneurs. However, the choice of policy sector remains unproblematized. For example, climate issues and regional economic and community development have garnered considerable attention (Huitema \& Meijerink, 2010; Lavee \& Cohen, 2019; Meijerink \& Huitema, 2010; Mintrom et al., 2014; Mintrom \& Luetjens, 2017), though not to the exclusion, for example, of science policy (Mintrom, 2013) and lately, crisis management and disaster preparedness (Anderson et al., 2019; Petridou \& Sparf, 2017). A research question arises: Are some substantive areas of public policy more conducive to policy entrepreneurship than others? This is an empirical question, but one where theorization could greatly assist in answering it.

The foregoing observations highlight how broader administrative and political systems influence the spaces in which would-be policy entrepreneurs operate. There would be merit in future research that explores explicitly the degree to which policy entrepreneurs consciously select the level of government in which they are active. Thinking along these lines suggests comparative studies would be a fruitful way forward for studying how policy entrepreneurs engage in specific issues, how they engage, and the relative merits of working at, say, the level of local government compared with state government or at the national level. 
Finally, further developing our understanding of the relational context of the policy entrepreneur has the potential to address agency and structure simultaneously. Networks influence the amount and kind of information and other resources exchanged between actors. Networks can also mitigate the risk and responsibility actors have to take. Finally, networks can buffer actors from external shocks, and facilitate coalition building (Christopoulos, 2006; Christpoloulos \& Ingold, 2011). Further investigation of the relational context of policy entrepreneurs through formal social network analysis could reveal how policy entrepreneurs relate to different kinds of actors and help us identify and distinguish them from other actors (Christopoulos, 2006; Christopoulos \& Ingold, 2015).

\section{Further Specifying the Strategies Policy Entrepreneurs Deploy}

A significant portion of the policy entrepreneurship literature has focused on the strategies they use (see, for example, Cairney, 2018; Frisch-Aviram et al., 2019; Meijerink \& Huitema, 2010; Mintrom, 2013; Mintrom \& Luetjens, 2017; Petridou, 2018; Petridou \& Sparf, 2017). Recent work by Frisch-Aviram et al. (2019) identified 20 distinct strategies in the literature published in the last four decades and developed a heuristic in an effort to understand when in the policy cycle and at which government level these strategies are used. Conversely, Capano and Galanti (2018) identified broad activity categories of strategies contingent on the stage of policy process and type of actor.

Here, we discuss how future research might improve our knowledge of the strategies used by policy entrepreneurs. We do so by considering first, how we could better appreciate the connection between operating contexts and strategies deployed; second, the value that could come from explicitly acknowledging that the strategies policy entrepreneurs deploy are also used by other actors in and around policy-making processes; and finally, how policy entrepreneurs cope with complexity.

While our understanding of the strategies policy entrepreneurs use is quite comprehensive, there is still much to be learnt from a theoretical perspective. The phenomenon of policy entrepreneurship lends itself to case study research and this contributes to limited overarching understanding of whether some strategies are a better fit to a particular policy sector rather than another. As mentioned elsewhere in this article, environmental policy and economic development policy feature prominently in the literature (Frisch-Aviram et al., 2019), while their intersection (Arnold et al., 2017) provides a terrain suitable for the investigation into nuances between entrepreneurs in favor of a policy vis-à-vis those working to promote its opposite.

While the distinctiveness of the policy entrepreneurs centers on their seeking policy change, the strategies they use are not unique to them and may be employed by leaders or policy brokers. Attempts to disentangle these actors include work by Capano and Galanti (2018), Christopoulos (2006), Christopoulos and Ingold (2015), Ingold and Christopoulos (2015), and Ingold and Varone (2012); see also Burt (2005). Though policy brokers and policy entrepreneurs are structurally very similar, their 
difference is purported to center on strategic behavior (entrepreneurs) vs. compromise (brokers). Social network analysis could potentially be used to shed light on this issue given the sophisticated metrics that can be incorporated within it.

Despite these conceptual differences, there exist overlaps between policy entrepreneurs and leaders, as well as policy entrepreneurs and brokers. We suggest that starting from considering commonalities between the specific strategies these actors use rather than points of difference between the actors themselves could propel our understanding of policy entrepreneurs forward. Starting with the assumption all political actors draw from a broad set of influence strategies in order to achieve their goals provides a sounder empirical foundation upon which to stress the unique ways that policy entrepreneurs deploy those strategies than continuing an effort that assumes policy entrepreneurs are uniquely different from other political actors on multiple dimensions, including the strategies they choose to deploy. This observation serves to further justify a research approach we discussed earlier-that is, delimiting policy entrepreneurs as a distinct class of actor.

Issues of policy complexity and the (expectation of) conflict have not been adequately addressed as factors inherent to policy sectors that may be contributing to the emergence of policy entrepreneurs. Zito (2001) articulated the relationship between the policy problem at hand and entrepreneurship in a study of epistemic communities and EU policy: "[T]he more complex and ambiguous the policy problems, the greater the entrepreneurial role epistemic communities will have in EU policy" (p. 588). We understand "greater" in this quote to refer to both degree and type of "entrepreneurial role," which is operationalized in the set of strategies deployed.

Another entry point for considering the strategies policy entrepreneurs deploy emerges from the growing complexity of many policy problems. The observation can be illustrated by considering the popularization of the notion of "wicked problems" (Head, 2008). Policy problems are becoming more complex and problem-solving methods predicated on linear causality do not provide adequate conceptualization of those problems. Inadequate conceptualization of the problem necessarily results in tendering of solutions that will inevitably come up short. In 1991, Roberts and King advocated for network-based, collaborative approaches to complex problems, arguing that the diversity of stakeholders could facilitate agreement at least as to the nature of a problem. Almost three decades later, the literature on complex adaptive systems attempts to theorize and understand complexity and contemporary societal and policy challenges and governance issues.

The departure point of complexity theory is the assumption that changes may not occur linearly as well as that small changes have the potential to cause large effects. Peters (2015) warns that in policy and politics, complexity has to be considered carefully because of its two dimensions, technical and political. Technical complexity refers to the underlying causes of a problem not being well understood or involving a large number of micro-macro interactions, whereas political complexity refers to a multitude of convergent interests involved in a policy domain. If we assume that increasingly policy-making settings are complex adaptive systems, then it follows logically that policy entrepreneurs operate in complex adaptive sessions (Duit \& Galaz, 2008). However, their role in such systems has not been adequately 
understood. Mintrom and Thomas (2018) have indicated how policy entrepreneurs might support the pursuit of the United Nations Sustainable Development Goals. The authors noted the importance of mapping the chains of connections that have to be established between the setting of goals and the change of actual on-the-ground practices. These are scaling strategies and explore the potential ripple effects at the macro level of change at the micro level. An explicit theoretical connection among policy entrepreneurs, complexity, and complex adaptive systems would at a minimum increase our understanding of when and how policy entrepreneurs deploy their strategies, especially in relation to the policy problem at hand.

\section{Improving the Measurement of the Impact Policy Entrepreneurs have in the Policy Process}

Policy entrepreneurs are political actors engaged in the pursuit of change. Therefore, it is appropriate to assess their impact and the connections between their actions and subsequent policy change. Here, we discuss, first, what change is being sought and, second, the potential value to be had in studying instances of failure in the pursuit of change.

When seeking to assess impact, we must first imagine what policy change looks like. Legislative change resulting in new policy has been employed as a definition of change in studies of policy entrepreneurship as it may be clearly demarcated and deconstructed to investigate entrepreneurial activity (see e.g., Ackrill \& Kay, 2011; Carter \& Scott, 2009; Kingdon 1984/2011; Mintrom, 2000). However, as our understanding of policy entrepreneurs has become more sophisticated and broadened to include actors such as public servants, the concept of change has also become more nuanced and perhaps less obvious than new or amended legislation.

Studies may focus on the implementation of a new policy. Arieli and Cohen (2013) investigated the role of policy entrepreneurs from Israel and Jordan in the cross-border collaboration between the two countries after the signing of a peace treaty between them. Petridou and Sparf (2017) showed how entrepreneurs facilitated the implementation of a national policy establishing a new national crisis coordination office. Also in the implementation stage, recent studies in Brazil (Falletti, 2010) and in Sweden (Petridou \& Olausson, 2017) showed how actions in local jurisdictions transformed policies and lay the foundation for the adoption of changes at the national level. Such studies illustrate that the measure of the impact prompted by actions of policy entrepreneurs goes beyond legislative change and it is contingent on context and across different points in time. What may have been considered innocuous change or a failure could be assessed as an example of a successful policy change if the researcher shifts the focus to a different level of governance, or assumes a longer time horizon, or both.

The lack of research on failed entrepreneurial attempts is also contingent on the prevalent assumption underpinning the research design of policy entrepreneurship studies. This is related to the issue of identification of the policy entrepreneur, namely that researchers tend to start with a policy change and then work backward. If any policy entrepreneurs were found to be part of the process, they would automatically be considered successful. 
This has two implications. First, any policy entrepreneurs working toward change not yet realized would not be identified; nor would unsuccessful policy entrepreneurs; that is, ones whose actions have not (yet) resulted in change. Therefore, we advocate a more robust research design, one including a combination of possibilities. In addition to the scenario in which both a policy entrepreneur and policy change are present, additional scenarios should include no policy entrepreneur present and no policy change; policy entrepreneur present and no policy change; and finally, no policy entrepreneur present and policy change. Such a research design would reveal the full range of logical relationships between policy entrepreneurs and policy change. It would go a long way toward alleviating the nagging concern of the literature on policy entrepreneurs; that is, the potential selection bias of choosing successful entrepreneurs because their actions resulted in observable change.

Given the quite reasonable bias among scientists to want to study cases where at least something interesting happened, it would make most sense to study cases of "no policy entrepreneur present and no policy change" within a broader comparative case study or quantitative research project. More broadly, a research design studying the full range of logical relationships would presuppose a set of comparable jurisdictional units. Though it could be conducted both qualitatively and quantitatively, a quantitative study would have the potential to explain variation among jurisdictions (such as U.S. states, European Union member states, or municipalities within a country) in a more nuanced way. It could reveal the connections between the strategies of policy entrepreneurs and the impact these have on promoting policy change.

\section{Identifying When Policy Entrepreneurs Prompt Widescale Change}

The actions taken by policy entrepreneurs might have impacts that reverberate beyond the jurisdiction in which the policy was first introduced. Indeed, it is reasonable to expect that policy entrepreneurs will choose specific jurisdictions as test sites or places to showcase successful policy innovation so that they can then promote similar policy innovation elsewhere in a broader governance system. We consider this process of second-order impacts to constitute dynamic change, whereby an initial change can catalyze more instances of change at other jurisdictional units, in a horizontal or vertical fashion. Literature on policy transfer (Dolowitz \& Marsh, 2000; Marsh \& Sharman, 2009) and policy diffusion (Shipan \& Volden, 2008, 2012) has for some time investigated the antecedents of the spreading of policy innovations. Mintrom (1997) argued that policy entrepreneurs, through relational management, are crucial (though of course not the only contributing factor) to the catalyzing of dynamic change processes.

Recent, theory-driven, quantitatively oriented research on policy diffusion has shed light on dynamic change. In a review of the literature, Shipan and Volden (2012) note that more extensive flows in contemporary politics increase the opportunities for jurisdictions to learn from elsewhere. What is more, while in the past evidence suggested that policy innovation spread more easily through neighboring jurisdictions, 
patterns of diffusion have recently become more differentiated. Additionally, some governments are better positioned to learn from others, especially well-resourced ones with professional bureaucracies. Competition among jurisdictions and coercion by higher levels of governance have the potential to convince a jurisdiction that adoption of a policy innovation is the right thing to do.

Shipan and Volden's (2012) assessment of the recent literature confirms earlier assumptions regarding the role policy entrepreneurs may play in the spreading of new policies across jurisdictional units (Mintrom, 1997). First, politics and the political context matter. The social acuity of policy entrepreneurs facilitates the interpretation of the political landscape in terms of how receptive a jurisdiction is in adopting a policy innovation. Additionally, the design of a policy plays a role in the potential ease of its adoption. Complex policies spread more slowly. Policies compatible with the current political environment spread more easily. Being able to demonstrate the benefits of a new policy, especially through the initiation of a trial, is a way to convince decision makers that adopting a new policy is the right thing to do and secure stakeholder buy-in. A relational approach (Adam \& Kriesi, 2007) holds promise in understanding how policy entrepreneurs create and make use of networks and structural advantages in them in their pursuit for dynamic change (Arnold et al., 2017). Finally, the effective framing of policy problems (Boushey, 2010, 2012), which is a well-documented strategy of policy entrepreneurs, can increase the likelihood that a problem will grasp the attention of policymakers and make them more receptive to its adoption.

\section{Conclusion}

The breadth, depth, and volume of research on policy entrepreneurs necessitates that we occasionally pause for reflection and take stock of the literature, while we ponder avenues for further research. In this article, we have pointed to a variety of ways that new research could propel the scholarship on policy entrepreneurs forward.

We propose that a fruitful avenue to explore agency and structure would involve ongoing, theory-driven empirical investigations into the connections between the localized actions of policy entrepreneurs and the emergence of widescale policy changes at the system level. Such a theory-driven research program would afford many opportunities to gain insights regarding mechanisms of change in contemporary local, national, and global politics in a variety of governance settings. More specifically, future research proposed in this article would trace the flow of intentionality, consequences, and interdependencies of actions by individual actors or teams of actors toward system-level changes. Such research would help to link micro-foundational studies of political agency with macro-level structural stability and change. At the same time, it would necessarily take into account the macro-to-micro connections and contingencies as well. In so doing, it would ensure that studies of microlevel actions are undertaken with due recognition given to the contexts (including the relational contexts) in which policy entrepreneurs operate, aiming at further understanding factors that enable and constrain their actions. 
Evangelia Petridou is assistant professor of public administration at Mid Sweden University. Her research interests include policy entrepreneurship, social networks, and crisis management.

Michael Mintrom is a professor of public policy at Monash University in Melbourne, Australia. His books include Public Policy: Investing for a Better World (Oxford University Press, 2019).

\section{References}

Ackrill, Robert, and Adrian Kay. 2011. "Multiple Streams in EU Policy-Making: The Case of the 2005 Sugar Reform." Journal of European Public Policy 18 (1): 72-89. https://doi.org/10.1080/13501 763.2011.520879.

Adam, Silke, and Hanspeter Kriesi. 2007. "The Network Approach." In Theories of the Policy Process, 2nd ed., ed. Paul A. Sabatier and Christopher M. Weible. Boulder, CO: Westview Press, 189-220.

Anderson, Sarah E., Rob A. DeLeo, and Kristin Taylor. 2019. "Policy Entrepreneurs, Legislators, and Agenda Setting: Information and Influence." Policy Studies Journal. https://doi.org/10.1111/ psj.12331.

Arieli, Tamar, and Nissim Cohen. 2013. "Policy Entrepreneurs and Post-ConflictCross-Border Cooperation: A Conceptual Framework and the Israeli-Jordanian Case." Policy Sciences 46 (3): 237-56.

Arnold, Gwen. 2020. "Does Entrepreneurship Work? Understanding What Policy Entrepreneurs Do and Whether It Matters." Policy Studies Journal. https:// doi.org/10.1111/psj.12388.

Arnold, Gwen, Le Anh Nguyen Long, and Madeline Gottlieb. 2017. "Social Networks and Policy Entrepreneurship: How Relationships Shape Municipal Decision Making about High-Volume Hydraulic Fracturing." Policy Studies Journal 45 (3): 414-41.

Bakir, Caner. 2009. "Policy Entrepreneurship and Institutional Change: Multilevel Governance of Central Banking Reform." Governance 22 (4): 571-98.

Battilana, Julie, Bernard Leca, and Eva Boxenbaum. 2009. "How Actors Change Institutions: Towards a Theory of Institutional Entrepreneurship." Academy of Management Annals 3 (1): 65-107.

Baumgartner, Frank R., and Bryan D. Jones. 1993/2009. Agendas and Instability in American Politics. Chicago, IL: University of Chicago Press.

Becker, Markus C., Thorbjørn Knudsen, and Richard Swedberg. 2012. “Schumpeter's Theory of Economic Development: 100 Years of Development." Journal of Evolutionary Economics 22 (5): 917-33.

Bornstein, David, and Susan Davis. 2010. Social Entrepreneurship: What Everyone Needs to Know. New York: Oxford University Press.

Boushey, Graeme. 2010. Policy Diffusion Dynamics in America. New York: Cambridge University Press.

- 2012. "Punctuated Equilibrium Theory and the Diffusion of Innovations." Policy Studies Journal 40 (1): $127-46$.

Burt, Ronald S. 2005. Brokerage and Closure: An Introduction to Social Capital. New York: Oxford University Press.

Cairney, Paul. 2013. "Standing on the Shoulders of Giants: How Do We Combine the Insights of Multiple Theories in Public Policy Studies?" Policy Studies Journal 41 (1): 1-21.

_. 2018. "Three Habits of Successful Policy Entrepreneurs." Policy \& Politics 46 (2): 199-215.

Callaghan, Timothy, and Steven Sylvester. 2019. "Private Citizens as Policy Entrepreneurs: Evidence from Autism Mandates and Parental Political Mobilization." Policy Studies Journal. https://doi. org $/ 10.1111 /$ psj.12346.

Capano, Giliberto, and Maria Tullia Galanti. 2018. "Policy Dynamics and Types of Agency: From Individual to Collective Patterns of Action." European Policy Analysis 4 (1): 23-47.

Carter, Neil, and Michael Jacobs. 2014. "Explaining Radical Policy Change: The Case of Climate Change and Energy Policy Under the British Labour Government 2006-10." Public Administration 92 (1): $125-41$.

Carter, Ralph G., and James M. Scott. 2009. Choosing to Lead: Understanding Congressional Foreign Policy Entrepreneurs. Durham, NC: Duke University Press.

Casson, Mark. 1982. The Entrepreneur: An Economic Theory. London: Rowman and Littlefield. 
Casson, Mark, and Marina Della Giusta. 2007. "Entrepreneurship and Social Capital: Analysing the Impact of Social Networks on Entrepreneurial Activity from a Rational Action Perspective." International Small Business Journal 25 (3): 220-44.

Christopoulos, Dimitrios C. 2006. "Relational Attributes of Political Entrepreneurs: A Network Perspective." Journal of European Public Policy 13 (5): 757-78.

Christopoulos, Dimitris, and Karin Ingold. 2011. "Distinguishing between Political Brokerage and Political Entrepreneurship." Procedia-Social and Behavioral Sciences 10 36-42.

_. 2015. "Exceptional or Just Well Connected? Political Entrepreneurs and Brokers in Policy Making." European Political Science Review 7 (3): 475-98.

Dewulf, Art, and René Bouwen. 2012. "Issue Framing in Conversations for Change: Discursive Interaction Strategies for 'Doing Differences'." The Journal of Applied Behavioral Science 48 (2): 168-93.

Dolan, Dana A. 2019. "Multiple Partial Couplings in the Multiple Streams Famework: The Case of Extreme Weather and Climate Change Adaptation." Policy Studies Journal. https:/ / doi.org/10.1111/psj.12341.

Dolowitz, David P., and David Marsh. 2000. "Learning from Abroad: The Role of Policy Transfer in Contemporary Policy-Making." Governance 13 (1): 5-23.

Duit, Andreas, and Victor Galaz. 2008. "Governance and Complexity-Emerging Issues for Governance Theory." Governance 21 (3): 311-35. https:/ / doi.org/10.1111/j.1468-0491.2008.00402.x.

Easton, David. 1969. "The New Revolution in Political Science." American Political Science Review 63 (4): 1051-61.

Evans, Peter B., Dietrich Rueschemeyer, and Theda Skocpol, eds. 1985. Bringing the State Back In. New York: Cambridge University Press.

Faling, Marijn. 2019. Strategizing Beyond Boundaries: Policy Entrepreneurship for Climate-Smart Agriculture. PhD diss., Wageningen University, Wageningen, the Netherlands.

Faling, Marijn, Robbert Biesbroek, Sylvia Karlsson-Vinkhuyzen, and Katrien Termeer. 2018. "Policy Entrepreneurship Across Boundaries: A Systematic Literature Review." Journal of Public Policy 39 (2): 1-30. https://doi.org/10.1017/S0143814X18000053.

Falleti, Tulia G. 2010. "Infiltrating the State: The Evolution of Health Care Reforms in Brazil, 1964-1988." In Explaining Institutional Change: Ambiguity, Agency, and Power, ed. James Mahoney, and Kathleen A. Thelen. Cambridge: Cambridge University Press, 38-62.

Feldman, Martha S., and Anne M. Khademian. 2002. "To Manage Is to Govern." Public Administration Review 62: 541-55.

Frisch-Aviram, Neomi, Nissim Cohen, and Itai Beeri. 2018. "Low-Level Bureaucrats, Local Government Regimes and Policy Entrepreneurship." Policy Sciences 51 (1): 39-57. https://doi.org/10.1007/s1107 7-017-9296-y.

—. 2019. "Wind(ow) of Change: A Systematic Review of Policy Entrepreneurship Characteristics and Strategies." Policy Studies Journal. https:/ / doi.org/10.1111/psj.12339.

Golan-Nadir, Niva, and Nissim Cohen. 2017. "The Role of Individual Agents in Promoting Peace Processes: Business People and Policy Entrepreneurship in the Israeli-Palestinian Conflict." Policy Studies 38 (1): 21-38.

Goldfinch, Shaun, and Paul 't Hart. 2003. "Leadership and Institutional Reform: Engineering Macroeconomic Policy Change in Australia." Governance 16: 235-70.

Goyal, Nihit, Michael Howlett, and Namrata Chindarkar. 2020. "Who Coupled Which Stream (s)? Policy Entrepreneurship and Innovation in the Energy-Water Nexus in Gujarat, India." Public Administration and Development 40 (1): 49-64.

Hall, Peter A., and Rosemary C. Taylor. 1996. "Political Science and the Three New Institutionalisms." Political Studies 44 (5): 936-57.

Hammond, Daniel R. 2013. "Policy Entrepreneurship in China's Response to Urban Poverty." Policy Studies Journal 41 (1): 119-46. https:/ / doi.org/10.1111/psj.12005.

Head, Brian W. 2008. "Wicked Problems in Public Policy." Public Policy 3 (2): 101-16.

Herweg, Nicole, Nikolaos Zahariadis, and Reimut Zohlnhöfer. 2018. "The Multiple Streams Framework: Foundations, Refinements, and Empirical Applications." In Theories of the Policy Process, 4th ed., ed. Christopher M. Weible, and Paul A. Sabatier. Boulder, CO: Westview Press, 17-53.

Howard, Cosmo. 2001. "Bureaucrats in the Social Policy Process: Administrative Policy Entrepreneurs and the Case of Working Nation." Australian Journal of Public Administration 60 (3): 56. https://doi. org/10.1111/1467-8500.00224.

Huitema, Dave, and Sander Meijerink. 2010. "Realizing Water Transitions: The Role of Policy Entrepreneurs in Water Policy Change." Ecology and Society 15 (2): 26. 
Ingold, Karin, and Dimitris Christopoulos. 2015. "The Networks of Political Entrepreneurs: A Case Study of Swiss Climate Policy." In Entrepreneurship in the Polis: Understanding Political Entrepreneurship, ed. Inga Narbutaite Aflaki, Evangelia Petridou, and Lee Miles. Burlington, VT: Ashgate, 17-30.

Ingold, Karin, and Frédéric Varone. 2012. "Treating Policy Brokers Seriously: Evidence From the Climate Policy." Journal of Public Administration Research and Theory 22 (2): 319-46.

Jones, Michael D., and Mark K. McBeth. 2010. "A Narrative Policy Framework: Clear Enough to Be Wrong?" Policy Studies Journal 38 (2): 329-53.

Jones, Michael D., Holly L. Peterson, Jonathan J. Pierce, Nicole Herweg, Amiel Bernal, Holly Lamberta Raney, and Nikolaos Zahariadis. 2016. "A River Runs Through It: A Multiple Streams Meta-Review." Policy Studies Journal 44 (1): 13-36. https:/ / doi.org/10.1111/psj.12115.

Jones, Michael D., and Claudio M. Radaelli. 2015. “The Narrative Policy Framework: Child or Monster?” Critical Policy Studies 9 (3): 339-355. https: / / doi.org/10.1080/19460171.2015.1053959.

Kingdon, John W. 1984/2011. Agendas, Alternatives, and Public Policies, 3rd ed. Boston, MA: Longman.

Kirzner, Israel M.. 1973. Competition and Entrepreneurship, Chicago: Mifflin.

. 1997. "Entrepreneurial Discovery and the Competitive Market Process: An Austrian Approach." Journal of Economic Literature 35 (1): 60-85.

Knill, Christoph, and Jale Tosun. 2012. "Governance Institutions and Policy Implementation in the European Union." In Constructing a Policy-Making State? Policy Dynamics in the EU, ed. Jeremy Richardson. Oxford: OUP, 309-33.

Lavee, Einat, and Nissim Cohen. 2019. "How Street-Level Bureaucrats Become Policy Entrepreneurs: The Case of Urban Renewal." Governance 32 (3): 475-92. https:/ / doi.org/10.1111/gove.12387.

Lawton, Ricky N., and Murray A. Rudd. 2014. “A Narrative Policy Approach to Environmental Conservation." Ambio 43 (7): 849-57.

Lindblom, Charles E. 1959. "The Science of Muddling Through." Public Administration Review 19 (2): 79-88.

_. 1968. The Policy-Making Process. Englewood Cliffs, NJ: Prentice-Hall.

_. 1979. "Still Muddling, Not Yet Through." Public Administration Review 39 (6): 517-26.

Litfin, Karen T. 2000. "Advocacy Coalitions along the Domestic-Foreign Frontier: Globalization and Canadian Climate Change Policy." Policy Studies Journal 28: 236-52.

Lu, Hongmei, Audrey L. Mayer, Adam M. Wellstead, and Shan Zhou. 2020. "Can the Dual Identity of Policy Entrepreneur and Policy Implementer Promote Successful Policy Adoption? Vertical Greening Policymaking in Shanghai, China." Journal of Asian Public Policy 13 113-28.

March, James G., and Johan P. Olsen. 1983. "The New Institutionalism: Organizational Factors in Political Life." American Political Science Review 78 (3): 734-49.

-1989. Rediscovering Institutions: The Organizational Basis of Politics. New York: Free Press.

Marsh, David, and Jason C. Sharman. 2009. "Policy Diffusion and Policy Transfer." Policy Studies 30 (3): 269-88.

McBeth, Mark K., and Elizabeth A. Shanahan. 2004. "Public Opinion for Sale: The Role of Policy Marketers in Greater Yellowstone Policy Conflict." Policy Sciences 37 319-38.

Meijerink, Sander, and Dave Huitema. 2010. "Policy Entrepreneurs and Change Strategies: Lessons from Sixteen Case Studies of Water Transitions around the Globe." Ecology and Society 15 (2): 21.

Mettler, Suzanne. 1998. Dividing Citizens: Gender and Federalism in New Deal Public Policy, Ithaca, NY: Cornell University Press.

Meydani, Assaf. 2015. "Political Entrepreneurs and Institutional Change: Governability, Liberal Political Culture, and the 1992 Electoral Reform in Israel." In Entrepreneurship in the Polis: Understanding Political Entrepreneurship, ed. Inga Narbutaité Aflaki, Evangelia Petridou, and Lee Miles. Burligton, VT: Ashgate, 87-102.

Mintrom, Michael. 1997. "Policy Entrepreneurs and the Diffusion of Innovation." American Journal of Political Science 41: 738-70.

. 2000. Policy Entrepreneurs and School Choice. Washington, DC: Georgetown University Press.

. 2013. "Policy Entrepreneurs and Controversial Science: Governing Human Embryonic Stem Cell Research." Journal of European Public Policy 20 (3): 442-57. https://doi.org/10.1080/13501 763.2012.761514.

- 2015. "Policy Entrepreneurs and Morality Politics: Learning from Failure and Success." In Entrepreneurship in the Polis: Understanding Political Entrepreneurship, ed. Inga Narbutaite Aflaki, Evangelia Petridou, and Lee Miles. Burlington, VT: Ashgate, 103-18.

- 2019. Policy Entrepreneurs and Dynamic Change. New York: Cambridge University Press. 
Mintrom, Michael, and Joannah Luetjens. 2017. "Policy Entrepreneurs and Problem Framing: The Case of Climate Change." Environment and Planning C: Politics and Space 35 (8): 1362-77.

- 2019. "International Policy Entrepreneurship. In The Oxford Handbook of Global Policy and Transnational Administration, ed. Stone, Diane \& Moloney, Kim. Oxford: Oxford University Press, 111.

Mintrom, Michael, and Philippa Norman. 2009. "Policy Entrepreneurship and Policy Change." Policy Studies Journal 37 (4): 649-67. https:/ / doi.org/10.1111/j.1541-0072.2009.00329.x.

Mintrom, Michael, Christopher Salisbury, and Joannah Luetjens. 2014. "Policy Entrepreneurs and Promotion of Australian State Knowledge Economies." Australian Journal of Political Science 49 (3): 423-38. https:/ / doi.org/10.1080/10361146.2014.934657.

Mintrom, Michael, and Madeline Thomas. 2018. "Policy Entrepreneurs and Collaborative Action: Pursuit of the Sustainable Development Goals." International Journal of Entrepreneurial Venturing 10 (2): 153-71.

Mintrom, Michael, and Sandra Vergari. 1996. "Advocacy Coalitions, Policy Entrepreneurs, and Policy Change." Policy Studies Journal 24: 420-34.

- 1998. "Policy Networks and Innovation Diffusion: The Case of State Education Reforms." Journal of Politics 60: 126-48.

Narbutaité Aflaki, Inga, Lee Miles, and Evangelia Petridou, eds. 2015. Entrepreneurship in the Polis: Understanding Political Entrepreneurship. Burlington, VT: Ashgate.

North, Douglass C. 1981. Structure and Change in Economic History. New York: Norton.

. 1990. Institutions, Institutional Change, and Economic Performance. New York: Cambridge University Press.

Ohemeng, Frank L. K., and Osee Kamga. 2020. “Administrative Leaders as Institutional Entrepreneurs in Developing Countries: A Study of The Development and Institutionalization of Performance Management in Ghana's Public Service." Public Administration and Development 40 (1): 87-100.

Ostrom, Elinor. 2009. Understanding Institutional Diversity. Princeton, NJ: Princeton University Press.

Peters, B. Guy. 2015. Advanced Introduction to Public Policy. Cheltenham, UK: Edward Elgar.

Petridou, Evangelia. 2014. “Theories of the Policy Process: Contemporary Scholarship and Future Directions." Policy Studies Journal 42: S12-32.

- 2017. Political Entrepreneurship in Swedish: Towards a (Re)theorization of Entrepreneurial Agency. PhD diss., Mid Sweden University.

- 2018. "Entrepreneurship in the Swedish Municipal Polis: The Case of Mer [*] Östersund." Policy Studies 39 (1): 70-89. https:/ / doi.org/10.1080/01442872.2018.1434872.

Petridou, Evangelia, and Pär M. Olausson. 2017. "Policy Entrepreneurship and Policy Transfer: Flood Risk Governance in Northern Sweden." Central European Journal of Public Policy 11 1-12.

Petridou, Evangelia, and Jörgen Sparf. 2017. "For Safety's Sake: The Strategies of Institutional Entrepreneurs and Bureaucratic Reforms in Swedish Crisis Management, 2001-2009." Policy and Society 36 (4): 556-74. https:/ / doi.org/10.1080/14494035.2017.1369677.

Powell Walter W., and Paul J. DiMaggio, eds. 1991. The New Institutionalism in Organizational Analysis. Chicago, IL: University of Chicago Press.

Roberts, Nancy C., and Paula J. King. 1991. "Policy Entrepreneurs: Their Activity Structure and Function in the Policy Process." Journal of Public Administration Research and Theory 1 (2): 147-75.

- 1996. Transforming Public Policy: Dynamics of Policy Entrepreneurship and Innovation. San Francisco, CA: Jossey-Bass.

Sabatier, Paul A. 1988. "An Advocacy Coalition Framework of Policy Change and the Role of PolicyOriented Learning Therein." Policy Sciences 21 (2-3): 129-68.

Sabatier, Paul A., and Hank Jenkins-Smith. 1993. Policy Change and Learning: An Advocacy Coalition Approach. Boulder, CO: Westview Press.

Sabatier, Paul A., and Christopher M. Weible, eds. 2014. Theories of the Policy Process 3rd edition, Boulder, CO: Westview Press.

Scharpf, Fritz W. 1997. Games Real Actors Play. Actor-Centered Institutionalism in Policy Research. Boulder, CO: Westview Press.

Schattschneider, Elmer E. 1960. The Semisovereign People: A Realist's View of Democracy in America. New York: Holt, Rinehart and Winston.

Schneider, Mark, and Paul Teske. 1992. “Toward a Theory of the Political Entrepreneur: Evidence from Local Government." American Political Science Review 86 (3): 737-47.

Schneider, Mark, and Paul Teske with Michael Mintrom. 1995. Public Entrepreneurs: Agents for Change in American Government. Princeton, NJ: Princeton University Press. 
Schumpeter, Joseph A. 1934. The Theory of Economic Development, trans. Redvers Opie. Cambridge, MA: Harvard University Press.

Shanahan, Elizabeth A., Mark K. McBeth, and Paul L. Hathaway. 2011. "Narrative Policy Framework: The Influence of Media Policy Narratives on Public Opinion." Politics E Policy 39 373-400.

Shanahan, Elizabeth A., Stephanie M. Adams, Michael D. Jones, and Mark K. McBeth. 2014. "The Blame Game: Narrative Persuasiveness of the Intentional Causal Mechanism." In The Science of Stories, ed. Michael D. Jones, Elizabeth A. Shanahan, and Mark K. McBeth. New York: Palgrave Macmillan, 69-88.

Shanahan, Elizabeth A., Michael D. Jones, Mark K. McBeth, and Claudio M. Radaelli. 2018. "The Narrative Policy Framework." In Theories of the Policy Process, 4th ed., ed. Christopher M. Weible, and Paul A. Sabatier. New York: Routlege, 173-213.

Sheingate, Adam D. 2003. "Political Entrepreneurship, Institutional Change, and American Political Development." Studies in American Political Development 17 (2): 185-203.

Shipan, Charles R., and Craig Volden. 2008. "The Mechanisms of Policy Diffusion." American Journal of Political Science 52 (4): 840-57.

- 2012. "Policy Diffusion: Seven Lessons for Scholars and Practitioners." Public Administration Review 72 (6): 788-96.

Shockley, Gordon E., Roger R. Stough, Kingsley E. Haynes, and Peter M. Frank. 2006. "Toward a Theory of Public Sector Entrepreneurship." International Journal of Entrepreneurship and Innovation Management 6 (3): 205-23.

Shpaizman, Ilana, Ori Swed, and Ami Pedahzur. 2016. "Policy Change Inch by Inch: Policy Entrepreneurs in the Holy Basin of Jerusalem." Public Administration 94 (4): 1042-58.

Stone, Deborah A. 2002. Policy Paradox: The Art of Political Decision Making. New York: WW Norton.

Svensson, Petra. 2019. "Formalized Policy Entrepreneurship as a Governance Tool for Policy Integration." International Journal of Public Administration 42 (14): 1212-21. https://doi.org/10.1080/01900 692.2019.1590401.

Tang, Na, Li Cheng, and Changkun Cai. 2020. "Making Collective Policy Entrepreneurship Work: The Case of China's Post-Disaster Reconstruction." Journal of Asian Public Policy 13 (1): 60-78.

Varone, Frédric, Steve Jacob, and Lieven de Winter. 2005. "Policy, Politics, and Policy Evaluation in Belgium." Evaluation 11 (3): 253-73.

Viñas, Verónica. 2009. “The European Union's Drive Towards Public Policy Evaluation: The Case of Spain." Evaluation 15 (4): 459-72.

Weible, Christopher M. 2018. "Moving Forward and Climbing Upward: Advancing Policy Process Research." In Theories of the Policy Process, 4th ed., ed. Christopher M. Weible, and Paul A. Sabatier. New York: Routledge, 363-78.

Weible, Christopher M., and Paul A. Sabatier. 2009. "Coalitions, Science, and Belief Change: Comparing Adversarial and Collaborative Policy Subsystems." Policy Studies Journal 37 (2): 195-212.

Weible, Christopher M., Paul A. Sabatier, and Kelly McQueen. 2009. "Themes and Variations: Taking Stock of the Advocacy Coalition Framework." Policy Studies Journal 37 (1): 121-40.

Zahariadis, Nikolaos. 2014. "Ambiguity and Multiple Streams." In Theories of the Policy Process, 3rd ed., ed. Paul A. Sabatier, and Christopher M. Weible. Boulder, CO: Westview Press, 25-58.

Zito, Anthony R.. 2001. "Epistemic Communities, Collective Entrepreneurship and European Integration." Journal of European Public Policy 8 585-603. 